\title{
Pemberitaan Injil di Tengah Masyarakat Pluralis
}

\author{
Alvin Budiman Kristian \\ Humas Sekolah Tinggi Teologi Excelsius \\ alvinbkristian@sttexcelsius.ac.id
}

\begin{abstract}
In the midst of the plurality of the people of this world. Then it cannot be denied that there are differences between one another. That diversity and differences is what is termed pluralism. As well as religion which is an important part of society, even each individual has a plurality phenomenon whose influence in society has a huge impact on the thinking of each individual. The differences between each religion and the truth claims and absolutes of each religion often cause considerable friction in society. In fact, it is not uncommon for many people to judge and make religion a tool of violence.
\end{abstract}

Keywords: Pluralism; Religion; Gospel; People; Mission

\begin{abstract}
Abstrak
Ditengah-tengah kemajemukkan masyarakat dunia ini. Maka tidak bisa dipungkiri adanya perbedaan antara satu dengan yang lainnya. Keragaman dan perbedaan-perbedaan itulah yang disebut dengan istilah pluralisme. Sebagaimana juga agama yang merupakan bagian yang penting dalam masyarakat, bahkan tiap-tiap individu mempunya fenomena pluralitas yang pengaruhnya di dalam masyarakat mempunyai dampak yang sangat besar bagi pemikiran tiap-tiap individu. Perbedaan masing-masing agama dan klaimklaim kebenaran serta kemutlakan tiap-tiap agama sering menimbulkan gesekan-gesekan yang cukup keras dalam masyarakat. Bahkan tidak jarang banyak orang menilai dan menjadikan agama sebagai alat kekerasan.
\end{abstract}

Kata Kunci: Pluralisme, Agama, Injil, Masyarakat, Misi 


\section{PENDAHULUAN}

Kehidupan Kristen tidak lepas dari penginjilan. Menurut Harianto GP penginjilan dapat dijabarkan secara operasional yaitu "memberitakan tentang Yesus Kristus dalam kuasa Roh Kudus kepada orang berdosa (dalam berita) yang disampaikan dengan penuh keyakinan agar orang berdosa tersebut bertobat dan menerima Yesus Kristus sebagai Juruselamat, menjadi anggota gereja yang bertanggung jawab untuk memuridkan orang lain guna memenangkan dunia bagi kejayaan Kristus sehingga membawa kemuliaan bagi Allah."1

Penginjilan sebagai tugas, pada mulanya ditanggapi oleh gereja sesuai dengan isi amanat yang diterimanya dari Tuhan Yesus. Alkitab memberikan catatancatatan penting tentang pergerakan gereja mula-mula dalam meresponi tugas ini. Sebagai bagian dari tugas utamanya gereja masa kini pun masih mengakui penginjilan sebagai tugas dan tanggung jawabnya. Menjadi pokok permasalahannya bagaimana gereja dan setiap orang percaya meningkatkan kefektifan penginjilan sebagai salah satu tugasnya, khususnya di tengah masyarakat yang majemuk (Pluralis). ${ }^{2}$
Ditengah-tengah kemajemukkan masyarakat dunia ini. Maka tidak bisa dipungkiri adanya perbedaan antara satu dengan yang lainnya. Keragaman dan perbedaan-perbedaan itulah yang disebut dengan istilah pluralisme. Sebagaimana juga agama yang merupakan bagian yang penting dalam masyarakat, bahkan tiap-tiap individu mempunya fenomena pluralitas yang pengaruhnya di dalam masyarakat mempunyai dampak yang sangat besar bagi pemikiran tiap-tiap individu. Perbedaan masing-masing agama dan klaim-klaim kebenaran serta kemutlakan tiap-tiap agama sering menimbulkan gesekan-gesekan yang cukup keras dalam masyarakat. Bahkan tidak jarang banyak orang menilai dan menjadikan agama sebagai alat kekerasan.

Melalui artikel ini, penulis akan menjabarkan pentingnya penginjilan, teori penginjilan, serta apa saja metode yang dilengkapi pula dengan aplikasi dalam pelaksanaan pemberitaan Injil di tengah masyarakat pluralis.

\section{METODOLOGI PENELITIAN}

Dalam meneliti artikel ini, penulis menggunakan metode penelitian pendekatan studi literatur.
${ }^{1}$ Harianto GP, Pengantar Misiologi (Yogyakarta: ANDI, 2012), 8.
${ }^{2}$ Manto Manurung, Skripsi: "Penginjilan di tengah Masyarakat Majemuk: Tantangan dan Solusinya" (Jakarta: STT Ekklesia, 2005), 1. 


\section{ANALISIS DAN HASIL PENELITIAN}

\section{$\underline{\text { Pengertian Penginjilan Secara Etimologis }}$}

Dalam Alkitab, baik dalam kitab-

kitab Perjanjian Lama maupun dan kitabkitab Perjanjian Baru, kata "penginjilan" tidak ditemukan secara hurufiah. Pada hakekatnya kata ini berasal dari bahasa Yunani, yaitu $\varepsilon \dot{u} \alpha \gamma \gamma \varepsilon \lambda \iota \xi \omega$ dibaca evanggeliso yang berarti "mengumumkan, memberitakan, atau membawa kabar baik, ${ }^{3}$ dan "memproklamasikan Injil atau menjadi pembawa kabar baik di dalam Yesus"

Dalam konteks aslinya kata "evanggeliso" merupakan satu istilah yang dipakai dalam kemiliteran Yunani. Kata ini memiliki arti "upah yang diberikan kepada pembawa berita kemenangan dari medan tempur, dan atau berita kemenangan itu sendiri." ${ }^{4}$ Kemudian orang Kristen menggunakan kata "evanggeliso" untuk menjelaskan "berita" tetang pengorbanan dan atau karya Yesus Kristus"5

Kata "evanggeliso" sinonim dengan kata " $\kappa \varepsilon \rho \iota \sigma \sigma \omega "$ dibaca kerysso. Kata ini pada mulanya adalah satu istilah yang dipakai untuk seorang utusan resmi yang menyampaikan pengumuman dari raja. ${ }^{6}$ Kata ini dalam bahasa Yunani memiliki arti

3James Strong, Strong's Exhaustive Concordance of The Bible (Iowa: Riverside Book and Bible House Iowa Falls), 33.

${ }^{4}$ Yakob Tomatala, Penginjilan Masa Kini 1 (Malang: Gandum Mas, 1998), 24.

${ }^{5}$ Ibid. mengumumkan sebagai seorang bentara, atau memproklamasikan kabar baik. Pengumuman tersebut pada hakekatnya sangat penting, sehingga tidak dapat dibantah atau ditunda. ${ }^{7}$

Dalam kitab-kitab Perjanjian Baru digunakan kata lain yang berhubungan dengan penginjilan seperti kata " $\delta l \delta \alpha \sigma \chi \omega$ " dibaca didasko artinya mengajat, atau mengajarkan. ${ }^{8} \quad$ Tuhan Yesus sering menggunakan penginjilan dengan cara ini, contoh penggunaannya dicatat dalam Mat. 10:7-15; 4:23; 7:28; 9:35; Mrk. 1:21; 6:6; Luk. 10:4-12. Kata kedua yaitu " $\mu \alpha \rho \tau \cup \rho \varepsilon \omega "$ dibaca martureo artinya bersaksi, atau memyampaikan kesaksian berdasarkan apa yang dialami. ${ }^{9}$ Penginjilan dengan cara ini juga dipakai oleh para rasul (Kis. 2:40).

Setelah menyelidiki arti kata "penginjilan" secara etimologis, maka dapat ditarik kesimpulan sebagai berikut bahwa "penginjilan" adalah: (1) Satu tugas untuk mengumumkan atau memberitakan kabar baik, dan atau kabar keselamatan di dalam Yesus Kristus. (2) Dilakukan dengan cara menyerukannya seperti seorang utusan raja yang sedang mengumumkan satu dekrit, yaitu dengan suara yang keras dan tegas, dan

6 _ Ensiklopedi Alkitab Masa Kini, (Jakarta: Yayasan Komunikasi Bina Kasih, 2008), 183.

${ }^{7}$ Yakob Tomatala, Penginjilan Masa Kini 2 (Malang: Gandum Mas, 1998), 21

${ }^{8}$ Ibid.

${ }^{9}$ Ibid, 22. 
dapat juga dilakukan dengan mengajar seperti kepada seorang murid, dan dengan bersaksi berdasarkan apa yang dialami oleh pemberita Injil tersebut. (3) Tugas penginjilan tidak dapat dibantah dan atau dilalaikan karena berita itu menyangkut keselamatan jiwa banyak orang yang dikasihi oleh pemberi perintah.

\section{$\underline{\text { Penginjilan dan Pekabaran Injil }}$}

Penginjilan tidak lepas dari misi. Keduanya saling berhubungan erat. Misi berkaitan dengan pengertian penginjilan secara filosofis, yaitu "rancangan dan karya Allah yang menghimpun bagi diri-Nya suatu umat untuk bersekutu, menyembah dan melayani Dia secara serasi-utuh bagi kejayaan kerajaan-Nya. ${ }^{10}$ Penginjilan diartikan sebagai memberitakan tentang Yesus Kristus dalam kuasa Roh Kudus kepada orang berdosa (dalam berita) yang disampaikan dengan penuh keyakinan agar orang berdosa tersebut bertobat dan menerima Yesus Kristus sebagai Juruselamat, menjadi anggota gereja yang bertanggung jawab untuk memuridkan orang lain guna memenangkan dunia bagi kejayaan Kristus sehingga membawa kemuliaan bagi Allah."11

Dari pengertian penginjilan ini kemudian muncul istilah pekabaran Injil.

\footnotetext{
${ }^{10}$ Harianto GP, Pengantar Misiologi, 8 .

${ }^{11}$ Ibid.

${ }^{12}$ Ibid.
}

Pekabaran Injil adalah tahap pertama dalam pekerjaan misi. Pekabaran Injil adalah suatu prokalami Injil Yesus Kristus yang berkuasa, mengena dan dapat dimengerti, agar manusia bertobat kepada Tuhan Yesus. ${ }^{12}$

\section{Dasar Alkitabiah Pekabaran Injil}

Secara sederhana Pekabaran Injil diartikan sebagai segala kiat atau upaya untuk membawa seseorang ke dalam anugerah keselamatan di dalam Kristus melalui penyampaian berita Injil. ${ }^{13}$

Memberitakan Injil adalah suatu kewajiban. Markus 16:15 berbunyi, "Lalu Ia berkata kepada mereka: "Pergilah ke seluruh dunia, beritakanlah Injil kepada segala makhluk." Tanpa Injil manusia akan binasa, semua manusia berdosa dan berada di bawah penghukuman Allah (Rm. 3:23; 6:23). Tanpa Tuhan Yesus semua manusia akan binasa (Yoh. 14:6). Alkitab mengajarkan bahwa tiap orang percaya mempunyai kuasa untuk menjadi saksi secara sistematis, "mulai dari Yerusalem, Yudea, Samaria, samapi ke ujung bumi" apabila ia hidup dibawah pimpinan Roh Kudus (Kis. 1:8). Alkitab memerintahkan untuk selalu siap memberitakan Injil baik atau tidak baik waktunya (2 Tim. 4:2)

\footnotetext{
13 _ Latihan Pemuridan Dasar (Surabaya: Lembaga Pelayanan Mahasiswa Indonesia., 2007), 1.
} 


\section{Metode Pemberitaan Injil di Tengah Masyarakat Pluralis}

Kehidupan masyarakat di Indonesia pada masa kini, terutama di daerah perkotaan menunjukkan satu keadaan yang semakin plural, dalam aktivitas sehari-hari, tingkat pendidikan, status sosial, suku, dan agama yang berkembang di tengah masyarakat.

Kehidupan masyarakat perkotaan yang majemuk membuat kehidupan di perkotaan penuh dengan persoalan. Di satu sisi, perkotaan menjadi tempat yang menjanjikan untuk menikmati hidup yang berkelimpahan secara materi dan menjadi tempat yang tepat untuk mewujudkan citatcitanya, tetapi bagi anggota masyarkat lainnya, kota merupakan tempat penindasan dan kesengsaraan. Dalam kehidupan masyarakat kota yang majemuk, sering kali timbul kesenjangan dalam berbagai aspek. Kesenjangan tersebut terjadi karena berbagai perbedaan yang sangat signifikan dalam berbagai aspek kehidupan.

Penginjilan sebagai salah satu tugas esensial gereja mengharuskan gereja untuk melakukannya, sekalipun ia berada di tempat yang penuh tantangan dan rintangan. Dalam melaksanakan tugas ini, gereja berada pada posisi yang sama seperti seseorang yang telah sah menjadi seorang alat negara khususnya "tentara". Apabila seseorang telah diangkat dan disumpah menjadi tentara, kemanapun ia ditugaskan ia harus siap, dan ia tidak dapat berkata saya tidak dapat ke sana sebab saya tidak suka.

\section{Tantangan-tantangan dalam Memberitakan} $\underline{\text { Injil di tengah Masyarakat Pluralis }}$

Di tengah masyarakat kota di Indonesia yang majemuk dengan segala keberagamannya, sangat mungkin sekali terdapat kelompok-kelompok dalam masyarakat. Diantaranya adalah kelompok masyarakat kaya dan kelompok masyarkat menengah ke bawah. Penginjilan di antara masyarakat perkotaan yang membentuk kelompok-kelompok tersebut, memberikan tantangan khusus kepada gereja. Penginjjilan di antara kelompok masyarakat kaya antara lain: (1) Lingkungan tempat tingggalnya dilengkapi dengan sistem pengamanan yang lebih ketat. (2) Biasanya adalah para pekerja, dan atau pemilik perusahaan, sehingga sulit untuk ditemui, kecuali sudah ada perjanjian khusus. (3) Memiliki rasa curiga yang tinggi, terutama kepada orang yang belum dikenal.

Sedangkan tantangan penginjilan di antara kelompok masyarakat menengah ke bawah adalah: (1) Beberapa di antaranya menjadi pekerja di berbagai perusahaan, kantor, atau pertokoan. Sebagai pekerja yang terikat dengan tuntutan-tuntutan yang telah disepakati dengan pihak perusahaan. Akibat pemenuhan tuntutan itu, sulit untuk bertemu kecuali pada hari-hari libut, ata pada jam istirahat kerja. (2) Ada yang tidak bekerja, 
memang lebih banyak waktu luang sehingga lebih mudah untuk ditemui, tetapi pada umumnya kurang tertarik dengan Injil seperti yang telah sering didengarkan dari banyak orang. Lebih memikirkan cara untuk mendapatkan pekerjaan sehingga bisa bertahan hidup.

\section{Bagaimana Cara Memberitakan Injil di tengah Masyarakat Pluralis?}

Dalam pemberitaan yang efektif selalu ada tiga faktor penting yang perlu diperhatikan oleh si pemberita, yaitu: ${ }^{14}$ (1) Kehadiran. Seorang yang ingin memberitakan Injil perlu hadir dengan jati diri yang jelas serta hidup dengan penuh integritas (Mat. 5:16). (2) Pemberitaan. Kehadiran di tengah konteks tidaklah cukup, firman Tuhan harus dibenarkan karena "Iman timbul dari pendengaran, pendengaran akan firman Kristus (Rm. 10:17). (3) Pola pendekatan. Pemberitaan haruslah disampaikan dengan cara-cara yang dapat diterima oleh pendengar (1 Kor. 9:19-23).

Ada tiga unsur utama proses perkabaran Injil, yaitu: ${ }^{15}$ (1) Manusia pelaku pekabaran Injil. Sebagai pembawa berita, ia haruslah seorang yang dapat dipercaya oleh si pendengar atau penerima berita, menguasai dan memiliki keyakinan yang kokoh akan kebenaran dari Injil

\footnotetext{
14 , Latihan Pemuridan Dasar, 2-3.

15 Ibid, 5-7.
}

keselamatan yang disampaikannya, serta mempuyai motivasi kasih yang tulus dalam menyampaikan kabar baik yang diberitakannya. Sebagai pendengar atau penerima berita, akan mudah menerima bila ia menerima dengan jelas berita yang disampaikan dan hatinya telah siap. (2) Kabar - isi berita dalam pemberitaan Injil. Pola pemberitaan akan menarik perhatian pendengar bila menjawab kebutuhan pendengar dan sesuai dengan pola pikir pendengar. Inti pemberitaan seharusnya berpusat pada berita Injil salah satunya bahwa Allah mengasihi manusia (Yoh. 3:16) dan mempunyai rencana yang indah bagi hidup manusia (Yoh. 10:10b). (3) Metode pola pendekatan dalam pemberitaan Injil. Pola pemberitaan harus berpusat pada prinsip komunikasi yang benar (Principle centered), bukannya berpusat pada metode atau diri sendiri. Pola pemberitaan juga seharusnya berpusat pada pendengar (Receiver centered). Pemberitaan yang berpusat pada pendengar, haruslah memperhatikan pendekatan yang digunakan. Perlu keseimbangan antara pendekatan persahabatan dan pendekatan konforntatif Ellis mengatakan: "Penginjilan 'mengkomunikasikan Injil' membutuhkan metode yang tepat guna."16 Artinya pada waktu gereja mengkomunikasikan Injil

${ }^{16}$ D. W. Ellis, Metode Penginjilan (Jakarta: Yayasan Komunikasi Bina Kasih/OMF, 1989), 6. 
haruslah menggunakan metode pendekatan yang tepat guna. Dengan demikian berita Injil bisa diseberangkan dan dipahami pendengarnya. Yesus adalah seorang tokoh penginjilan yang paling efektif dan kontekstua. Jadi Yesus layak untuk dijadikan contoh dan teladan ketika gereja hendak melaksanakan penginjilan yang efektif. Berdasarkan contoh-contoh metode penginjilan Tuhan Yesus kepada masyarakat di sekitar-Nya memberikan beberapa kebenaran yang masih relevan untuk diterapkan dalam gereja masa kini, antara lain: (1) Gereja haruslah memikirkan metode yang paling tepat ketika akan melaksanakan tugasnya di antara masyarakat di sekitarnya. Gereja perlu menyadari bahwa keefektifan penginjilan adalah bergantung kepada metode penginjilan yang gereja gunakan. Metode penginjilan yang efektif adalah metode yang tepat guna untuk diterapkan dalam konteks masyarakt yang sedang akan diinjili. (2) Gereja jangan menetapkan satu metode tertentu menjadi metode baku penginjilan, karena setiap orang berbeda dalam meresponi berita Injil. (3) Gereja harulah memilki hati yang mengasihi jiwajiwa sama seperti Yesus telah mengasihi gereja-Nya. Melaksanakan penginjilan tanpa dasar kasih cenderung mendorong gereja menjadi hakim kepada orang-orang berdosa.
Gereja akan cenderung bertindak sama seperti orang-orang Farisi dan para ahli Taurat. (4) Metode yang dipakai dalam penginjilan haruslah fleksibel, tetapi tidak berarti bahwa gereja dapat memilih metode yang bersifat kompromi terhadap dosa.

Rahasia penginjilan yang efektif tidak hanya menyampaikan pesan Kristus, tetapi mengikuti metodologi Kristus. ${ }^{17}$ Metodologi ini pada prinsipnya adalah berdasar kepada kerinduan gereja agar setiap objeknya menerima dan mengalami kuasa Injil. Oleh karena itu gereja harus belajar peka untuk menemukan metode yang paling efektif.

Kitab-kitab Perjanjian Baru mencatat ada empat metode penginjilan, diantaranya adalah Penginjilan di depan banyak orang, penginjilan pribadi, penginjilan dalam kelompok dan penginjilan perkunjungan rumah.

\section{APLIKASI}

Kitab-kitab Perjanjian Baru mencatat empat metode penginjilan. Berikut empat metode tesebut beserta aplikasinya: Pertama, Penginjilan di depan banyak orang. Penginjilan di depan orang banyak seringkali dilakukan dalam zaman Perjanjian Baru. Penginjilan di depan orang banyak biasanya dilakukan di Sinagoge-Sinagoge. Dalam

\footnotetext{
${ }^{17}$ Rick Warren, Pertumbuhan Gereja Masa Kini (Malang: Gandum Mas, 1999), 192.
} 
Alkitab dapat ditemukan bahwa Yesus mengajar di rumah-rumah ibadat (Luk. 4:14, 15), Petrus dan Yohanes memberitakan firman hidup di rumah ibadat atas perintah Allah (Kis. 5:21-25). Penginjilan di depan umum juga biasa dilakukan di tempat-tempat dimana terdapat orang banyak seperti di bukit (Mat. 5:1-12), di kota (Luk. 4:42-44), peristiwa setelah pentakosta (Kis. 2:14-40).

Penginjilan dengan metode ini kalau diterapkan di dunia masa kini, dapat dilakukan di tempat-tempat ibadah, dan di Kebaktian Kebangunan Rohani yang diadakan di lapangan-lapangan besar. Apabila dilaksanakan dengan sunguhsungguh metode ini dapat menjadi sangat efektif, telebih lagi kalau kuasa Allah diizinkan bekeraya. Metode ini tidak memerlukan pengenalan secara pribadi yang medalam kepada para pendengarnya. Dalam penginjilan dengan metode ini hanya diperlukan kerelaan untuk mendengar dan keberania untuk memberitakan Injil keselamatan.

Kedua, Penginjilan Pribadi. Metode penginjilan pribadi adalah metode penginjilan yang disesuaikan dengan daya nalar dari penerima Injil itu. Dalam pelayanan Yesus, Ia pun seing melakukan penginjilan pribadi. Sebagai contoh: penginjilan kepada peremua Samaria, Matius Lewi dan Zakheus. Metode ini menjadi efektif apabila penginjil dapat menjalin persahabatan dengan orang yang sedang akan diinjili. Penginjilan dengan metode ini sebaiknya bekerja sama dengan gereja lokal sehingga orang-orang yang telah menerima Injil dapat diintegrasikan dengan gereja lokal.

Ketiga, Penginjilan dalam kelompok. Penginjilan dalam kelompok ini lebihb bersifat kekeluargaan. Setiap anggota dapat berinteraksi tentang masalah-masalah pribadi dan masalah kerohanian kepada sesama anggota lainnya. Sebagai contoh Yesus memilih dua belas murid dan membimbing secara khusus, dan Ia membagikan hidupnya sepenuh waktu.

Penginjilan dalam kelompok merupakan penginjilan yang menuntut satu cara hidup yang sesuai dengan isi Injil itu sendiri. Seorang penginjil tidak hanya menginjili dengan kata-kata, tetapi juga dengan bukti nyata yang dapat dilihat oleh orang-orang yang sedang diinjili dalam kelompok itu.

Keempat, Penginjilan perkunjungan rumah. Dalam pelayanan Yesus, terkadang Yesus melakukan perkunjungan ke rumahrumah, antara lain: ke rumah Maria dan Marta (Luk. 10:38-42) dan ke rumah Zakheus (Luk. 19:1-10). Petrus penginjilan di rumah Kornelius (Kis. 10), Paulus penginjilan di kota Filipi di rumah Lidia (Kis. 16:15). Penginjilan ini lebih bersifat 
mengutamakan orang-orang yang ada di dalam rumah yang dimaksudkan.

\section{KESIMPULAN}

Kehidupan Kristen tidak lepas dari penginjilan. Rahasia penginjilan yang efektif tidak hanya menyampaikan pesan Kristus, tetapi mengikuti metodologi Kristus. Metodologi ini pada prinsipnya adalah berdasar kepada kerinduan gereja agar setiap objeknya menerima dan mengalami kuasa Injil. Oleh karena itu gereja harus belajar peka untuk menemukan metode yang paling efektif.

Ada empat metode penginjilan yang bisa dipakai yang diajarkan oleh kitab-kitab Perjanjian Baru diantaranya adalah Penginjilan di depan banyak orang, penginjilan pribadi, penginjilan dalam kelompok dan penginjilan perkunjungan rumah.

\section{DAFTAR PUSTAKA}

- Ensiklopedi Alkitab Masa Kini. Jakarta: Yayasan Komunikasi Bina Kasih, 2008.

Latihan Pemuridan Dasar. Surabaya: Lembaga Pelayanan Mahasiswa Indonesia, 2007.

Ellis, D. W. Metode Penginjilan. Jakarta: Yayasan Komunikasi Bina Kasih/OMF, 1989.

GP, Harianto. Pengantar Misiologi. Yogyakarta: ANDI, 2012.
Manurung, Manto. Skripsi: "Penginjilan di tengah Masyarakat Majemuk: Tantangan dan Solusinya". Jakarta: STT Ekklesia, 2005.

Strong, James. Strong's Exhaustive Concordance of The Bible. Iowa: Riverside Book and Bible House Iowa Falls.

Tomatala, Yakob. Penginjilan Masa Kini 1. Malang: Gandum Mas, 1998.

Tomatala, Yakob. Penginjilan Masa Kini 2. Malang: Gandum Mas, 1998.

Warren, Rick. Pertumbuhan Gereja Masa Kini. Malang: Gandum Mas, 1999. 
Excelsis Deo: Jurnal Teologi, Misiologi, dan Pendidikan 